\title{
MARKETS OF ORNAMENTAL PLANTS AND POSTHARVEST PHYSIOLOGY IN CUT FLOWERS
}

\author{
Kenji Yamane
}

Laboratory of Horticulture, Faculty of Agriculture, Utsunomiya University, Utsunomiya, Tochigi 321-8505, Japan

\begin{abstract}
Ornamental plants such as cut flowers and potted plants are traded around the world. In Japanese cut flower markets, flowers for business purposes and traditional flower arrangement classes are decreasing, while those for gifts and household use are increasing. There has been an increasing import of flowers from Malaysia, China, Columbia and other countries. The Netherlands occupies more than half of the worldwide exports of flowers. Postharvest technology is necessary to reduce the loss and provide consumers with high-quality flowers. There are many factors involved in senescence of cut flowers, including ethylene, water relation, soluble carbohydrate level, oxidative stress and programmed cell death. Ethylene inhibitors like STS and 1-MCP can inhibit ethylene actions and prolong the vase life of ethylene-sensitive flowers. The treatment of sugar and germicide improves carbohydrate level and water relation of cut flowers, resulting in prolonging their vase life. Physiology of cut flowers has been discussed and several methods of extending the vase life were introduced.
\end{abstract}

Keywords:Cut flowers, Market, Ethylene, Water relation, Carbohydrate, Programmed cell death

Markets of Ornamental Plants

Ornamental plants are widely used in the world as cut flower, cut branch, cut foliage, potted plant, bedding plant, garden tree and so on (Yamane, 2006). In cut flowers, chrysanthemum, rose, carnation and lily have a high popularity in the world market.

In Japan, the production and consumption of ornamentals plants had increased during the rapid economic growth period from 1970 to 1990 (Yamane, 2006). In the 1990s, lots of Japanese flower wholesale markets were combined into bigger ones. Dutch auction with electronic clock transaction is introduced in such new wholesale markets.

In Japanese cut flower markets, flowers for business purposes and traditional flower arrangement classes are decreasing (Yamane, 2006). On the other hand, those for gifts and household use are increasing. Chrysanthemum, rose, lily, carnation, orchid and Eustoma are major items in Japanese market. Consumption of these flowers concentrates on specific days such as Mother's Day, Buddhist services performed during the equinox, Christmas and the New Year. Chrysanthemums are generally used for decorations in funeral ceremonies, cemeteries and traditional flower arrangements, but many gorgeous cultivars of standard and spray types have been bred for several purposes. On Mother's Day, especially carnation has symbolic meanings. Phalaenopsis,
Cymbidium, hydrangea and cyclamen are popular as potted plants for gifts and house use.

Japanese consumption of floriculture crops reached 850-900 billion JPY in retail in 2013(FloraCulture, 2014). According to a household budget survey conducted by Japan's Ministry of Internal Affairs and Communications, a household spent 9,408 JPY for cut flowers and 8,478 JPY for pot plants (FloraCulture, 2014). OTA Floricuture Ltd., the Japan's largest auction, has 26 billion JPY turn over in 2014.

There has been an increasing import of flowers from Malaysia, China, Columbia, Korea, Taiwan and Thailand and other countries (FloraCulture, 2014). Since the unit price of cut flowers has stagnated in the Japanese markets, cut flowers are sold as a bouquet or a flower basket to raise value.

The UK, Germany and the USA are the top three countries in flower importation. Supermarkets in UK had successfully caught the demand of consumers and raised the national consumption during 1990s and early 2000s. Among the exporters, the Netherlands occupies more than half of the worldwide exports of flowers. Dutch auctions introduced Electric clock auctions. Recently, more and more remote purchasing systems have been introduced. It enables traders from around the world to purchase products online, using their PCs or mobile phones. In 2007, 
Please cite this article as:

Yamane, Reviews in Agricultural Science, 3:36-39, 2015

Doi: $10.7831 /$ ras.3.36

Aalsmeer and FloraHolland, both of which are flower auctions in the Netherlands, merged into a huge market. In 2014, the product turnover of the new FloraHolland was 4.5 billion EUR ( 600 billion JPY) (FloraHolland, 2015) .

\section{Senescence of Ethylene-sensitive Flowers}

Halevy and Mayak (1981), Van Doorn and Woltering (2008) and Ichimura (2010) reviewed papers on various factors of flower senescence.

Ethylene is one of the most important plant hormones to control flower senescence. A wide range of flowers is affected by ethylene, but sensitivity to ethylene varies according to species or cultivars (Van Doorn, 2001). High sensitivity to ethylene can be seen in carnation, delphinium, Cattleya, Eustoma, sweet pea, Gypsophila and snapdragon (Woltering and Van Doorn, 1988). Some flowers, on the other hand, show lower sensitivity; chrysanthemum, Dutch iris and gladiolus. Ethylene induces wilting, fading, abscission and other damage in ethylene-sensitive flowers (Woltering and Van Doorn, 1988). 'Sleepiness', the in-rolling of carnations petals, is a typical phenomenon induced by ethylene (Nichols, 1968). Exogenous ethylene can promote the synthesis of ethylene in plants. The system of autocatalytic ethylene production is common to both flower senescence and fruit ripening. Time course of ethylene production shows some typical patterns: a low steady rate, an accelerated rise and a last declining phase. The peak of ethylene production is termed as 'climacteric rise'.

Ethylene is synthesized through the following pathway: L-methionine $\rightarrow$ S-adenosyl-L-methionine $(\mathrm{SAM}) \rightarrow$ 1-aminocyclopropane-1-carboxylate (ACC) $\rightarrow$ ethylene (Yang and Hoffman, 1984). ACC synthase (ACS) and ACC oxidase (ACO) catalyse the last two reactions, respectively. In carnation (Dianthus caryophyllus), it is reported that several genes encode ACS ( $D C$ $A C S$ 1, DC-ACS 2 and DC-ACS 3) (Jones and Woodson, 1999) and another one serves to encode ACO ( $D C$-ACO 1) (Wang and Woodson, 1991). In the last step, carbon dioxide can inhibit the oxidation of ACC to ethylene.

In plants, ethylene is perceived by a family of membraneassociated ethylene receptors, followed by regulation of the activity of CONSTITUTIVE TRIPLE RESPONSE1 (CTR1), a raf-like mitogen-activated protein kinase kinase kinase (MAPKKK) as a negative regulator of the ethylene responses (Kieber et al., 1993). ETR1 homologues have been isolated from diverse flower species including rose, carnation and Delphinium. Ethylene production and petal wilting in cut carnation was well reviewed by Satoh (2011) .

Aminoethoxyvinyl glycine (AVG) specifically can inhibit ethylene synthesis by blocking the conversion of SAM to ACC. However, AVG is too expensive for commercial use in cut flowers. Silver ions $\left(\mathrm{Ag}^{+}\right)$are also be able to inhibit ethylene action in plants by combining specifically with ethylene receptors (Beyer, 1976). Silver thiosulfate (STS), negatively charged complex, can move from the base of the cut stem to flowers and leaves through xylem, blocking ethylene action and prolonging vase life of ethylenesensitive flowers (Veen, 1979). STS is the most popular chemical in the postharvest of ornamental plants although environmental contamination by silver should be carefully prevented.

1-Methylcyclopropene (1-MCP), an inhibitor of ethylene action, can prevent ethylene effects on flower senescence (Serek et al., 1994). 1-MCP is in gas form, therefore, powdery compounds which release 1-MCP are developed and commercially used for storage of fruits and flowers.

\section{Other Factors of Flower Senescence}

Termination of most of the cut flowers is partly characterized by wilting that is induced by less water uptake, high transpiration and low capacity of the flower tissue to retain water. In roses, a decrease rate of water conductivity and high transpiration rate induce the loss of petal turgidity and finally 'bent neck', which occurs often just below the floret (Marousky, 1969). Vascular blockage in stems can be induced by microbial growth, air embolism and a gummy substance produced by stems (Ichimura, 2010). Clean water and germicides can control microorganisms and maintain water uptake of cut flowers. Membrane permeability and osmotic potential are key factors for the ability of petal cells to retain water.

Reducing sugars are the major constituents of the sugar pool of mature petals (Halevy and Mayak, 1981). The starch content is important in woody plants like roses. The rate of respiration in flowers rises to its maximum at which flowers start to bloom, followed by a gradual decline as flowers mature. When the flower starts to wilt, it shows an increasing respiration over a relatively short period, and then shows a decrease. It is similar to 'climacteric rise' in respiration of many fruits. Because carbohydrate levels in cut flowers affect their vase life, sugar treatment on vase solution after harvest is effective to supplying sugars to flowers (Ichimura, 2010). Sucrose and other metabolic sugars like glucose and fructose are effective in prolonging the vase life of cut flowers, while excessive concentration of sucrose, a sort of disaccharide, could induce leaf wilting in some flowers. According to concentration of sugar, there are three types of use as follows; high concentration of sugar is used for pulsing (short pre-treatment), intermediate one is for bud-opening, and low for holding solution at consumers. In flowers with spikes like gladiolus, soluble sugars are transported from senescing lower florets to blooming upper florets inside the spikes (Yamane et al., 1993). They have a recycling system of sugars or other substances.

When a petal wilts, a degradation of the fatty acids in membranes will occur (Borochov et al., 1982). It seems to be 
mediated through non-enzymatic oxidative processes. Reactive oxygen species (ROS) generated by flower tissues and the environment could affect flower senescence (Droillard et al., 1987). Antioxidant enzymes such as superoxide dismutase and ascorbate peroxidase may be involved in flower senescence, but their roles are different in each species. Treatments with antioxidants such as sodium benzoate and 3,4,5-trichlorophenol inhibited petal senescence in carnations (Paulin et al., 1986). However, these effects of antioxidants seem to be emphasized at the final wilting stage.

In gladiolus, cycloheximide, a protein inhibitor, delayed the florets senescence (Yamane and Ogata, 1995), suggesting that protein synthesis is involved in senescence. Yamada (2003) demonstrated that DNA fragmentation and chromatin condensation were involved in flower senescence of gladiolus. In ephemeral flowers like morning glory, the process of opening and wilting is well controlled by genetic programs (Yamada et al., 2006). Physiological changes in these senescing flowers are considered to be processes of autophagic cell death which is a type of programmed cell death (PCD) in plant (Van Doorn and Woltering, 2008). PCD is involved in the senescence of morning glory (Yamada et al., 2006), Alstroemeria (Wagstaff et al., 2003), Hemerocallis (Panavas et al., 1998), Dutch iris (Van Doorn et al., 2003) and other flowers.

Some physiological changes such as loss of membrane integrity, an increase of ROS and activation of proteases, are associated with PCD (Van Doorn and Woltering, 2008). It is difficult to control PCD without inhibitors of protein synthesis since a range of transcription factors and regulators are differentially expressed in petal senescence. Recently, Shibuya et al. (2014) reported that EPHEMERAL1 (EPH1) is a key regulator of petal wilting and is involved in the expression of PCD-related genes, including genes for plant caspase (cysteine-protenase) and autophagy.

Trehalose, a nonreducing disaccharide consisting of two glucose units, markedly suppressed water loss and prolonged the vase life of florets in gladiolus (Otsubo and Iwaya-Inoue, 2000) and delayed PCD in gladiolus flowers (Yamada, 2003). The mechanism of trealose, however, is still not cleared well.

\section{How Can You Prolong The Vase Life?}

Breeders of flowers have technical data for the vase life of cut flowers and the shelf life of potted plants of their commercial varieties. Growers and traders should choose better varieties for markets. The most important factors in pre-harvest conditions seem to be the total amount of light energy in sun plants like carnation and chrysanthemums. Light intensity and temperature have affected on the longevity of flowers by affecting the inherent carbohydrate level. Harvest stage is also important.
Pulse treatments of STS were performed in carnations, delphiniums, Eustoma and so on. Treatments of germicides such as quinoline compound and quaternary ammonium compounds can inhibit microbial growth (Ichimura, 2010). Many commercial products including some sugars and germicide are available.

During transportation, temperature, humidity, air quality, packaging and storage patterns are important factors. In transportation, cardboard boxes used to be dominant but wet transportation in buckets is recently spreading for cut roses, Eustoma, carnations and so on (Ichimura, 2010). Vertical transport is desirable since flower stem and inflorescence often bend as a response to gravity when they are held horizontally.

Clean water can promote water absorption and keep the vase life longer. Supplying of flower foods such as sugars can prolong the vase life but consumers should care about hygiene of vase solution. Re-cutting of the base of stems avoid vascular blockage and air embolism, resulting more water uptake and better ornamental quality.

Controlled atmosphere (CA) and modified atmosphere (MA) are used for extending the postharvest longevity of various fruits and vegetables. In the experiment for cut carnation florets, active MA (initial gas, $2.75 \%$ for $\mathrm{CO}_{2}$ and $11.5 \%$ for $\mathrm{O}_{2}$ ) for 2 days repressed $D C$-ACS 2 and $D C$ - $A C O$ 1, decreased ethylene production, and thereby prolonged the longevity (Burana et al., 2014). High $\mathrm{CO}_{2}$ in MA and short-term CA is feasible to improve the qualities of potted and cut flowers.

\section{Acknowledgement}

I appreciate Mr. Koji Yamane, English education major, faculty of education in Utsunomiya University, for reviewing English of this paper.

\section{References}

Beyer EM (1976) A potent inhibitor of ethylene action in plants. Plant Physiol., 58: 268-271.

Borochov A, Halevy AH and Shinitzky M (1982) Senescence and the fluidity of rose petal membranes. Relationship to phospholipid metabolism. Plant Physiol., 69: 296-299.

Burana C, Kurokura T, Yamaki Y and Yamane K (2014) Modified atmosphere (MA) and 1-methylcyclopropene (1-MCP) combination treatment extends the postharvest life of carnations. Environmental Control in Biology, 52:131-136.

Droillard MJ, Paulin A and Massot JC (1987) Free radical production, catalase and superoxide dismutase activities and membrane integrity during senescence of petals of cut carnations (Dianthus caryophyllus). Physiol. Plant., 71: 197-202.

FloraCulture (2014) Japan in Focus. December 2014. <www. FloraCultureInternational.com.> 
FloraHolland (2015) 2014 year of change for FloraHolland. $<$ https://www.floraholland.com/en/about-floraholland/>

Halevy AH and Mayak S (1981) Senescence and postharvest physiology of cut flowers. Part 2. Hort. Rev., 3: 59-143.

Ichimura K (2010) Post-harvest physiology of cut flowers: Progress and future aspects. Bull. Natl. Inst. Flor. Sci., 10:11-53.

Jones, ML and Woodson WR (1999) Differential expression of three members of the 1-aminocyclopropane-1-carboxylate synthase gene family in carnation. Plant Physiol., 119: 755-764.

Kieber JJ, Rothenberg M, Roman G, Feldmann KA and Ecker JR (1993) CTR1, a negative regulator of the ethylene response pathway in Arabidopsis, encodes a member of the Raf family of protein kinases. Cell, 72:427-441.

Marousky FJ (1969) Vascular blockage, water absorption, stomatal opening, and respiration of cut 'Better Times' roses treated with 8-hydroxyquinoline citrate and sucrose. J. Am. Soc. Hort. Sci., 94: 223-226.

Nichols R (1968) The response of carnation (Dianthus caryophyllus) to ethylene. J. Hort. Sci., 43: 335-349.

Otsubo M and Iwaya-Inoue M (2000) Trehalose delays senescence in cut gladiolus spikes. HortScience, 35 :1107-1110.

Panavas T, Reid PD and Rubinstein B (1998) Programmed cell death of daylily petals: activities of wall-based enzymes and effects of heat shock. Plant Physiology and Biochemistry, 36:379-388.

Paulin A, Droillard MJ and Bureau JM (1986) Effect of a free radical scavenger, 3,4,5-trichlorophenol, on ethylene production and on changes in lipids and membrane integrity during senescence of petals of cut carnation (Dianthus caryophyllus). Physiol. Plant., 67: 465-471.

Satoh S (2011) Ethylene production and petal wilting during senescence of cut carnation (Dianthus caryophyllus) flowers and prolonging their vase life by genetic transformation. J. Japan. Soc. Hort. Sci., 80: 127-135.

Serek M, Sisler EC and Reid MS (1994) Novel gaseous ethylene binding inhibitor prevents ethylene effects in potted flowering plants. J. Am. Soc. Hort. Sci., 119: 1230-1233.

Shibuya K, Shimizu K, Niki T and Ichimura K (2014) Identification of a NAC transcription factor, EPHEMERAL1, that controls petal senescence in Japanese morning glory. Plant J., 79:1044-1051.

Yamada T, Takatsu Y, Kasumi M, Ichimura K, van Doorn WG (2006) Nuclear fragmentation and DNA degradation during programmed cell death in petals of morning glory (Ipomoea nil). Plant, 224:1279-1290.

Yamada T, Takatsu Y, Manabe T, Kasumi M and Marubashi W (2003) Suppressive effect of trehalose on apoptotic cell death leading to petal senescence in ethylene-insensitive flowers of gladiolus. Plant Science 4:213-221.

Yamane K (2006) Marketing system of horticultural crops. Horticulture in Japan 2006. pp.11-14.Shokado-shoten. Kyoto.

Yamane K, Abiru S, Fujishige N, Sakiyama R and Ogata R (1993) Export of soluble sugars and increase in membrane permeability of gladiolus florets during senescence. J. Japan. Soc. Hort. Sci., 62: 575-580.

Yamane K and Ogata R (1995) Effects of cycloheximide on physiological parameters of gladiolus florets during growth and senescence. J. Japan. Soc. Hort. Sci., 64: 411-416.

Yang SF and Hoffman NE (1984) Ethylene biosynthesis and its regulation in higher plants. Ann. Rev. Plant Physiol., 35: 155-189.

Van Doorn W (2001) Categories of petal senescence and abscission: a re-evaluation. Ann. Bot., 87: 447-456.

Van Doorn WG, Balk PA, van Houwelingen AM, Hoeberichts FA, Hall RD, Vorst O, van der Schoot $\mathrm{C}$ and van Wordragen MF (2003) Gene expression during anthesis and senescence in Iris flowers. Plant Mol. Biol., 53: 845-863.

Van Doorn W and Woltering EJ (2008) Physiology and molecular biology of petal senescence. J. Exp. Bot., 59: 453-480.

Veen, H (1979) Effects of silver on ethylene synthesis and action in cut carnations. Planta, 145: 467-470.

Wagstaff C, Malcom P, Arfan R, Leverentz MK, Griffith G, Thomas B, Stead AD and Rogers H (2003) Programmed cell death (PCD) processes begin extremely early in Alstroemeria petal senescence. New Phytologist, 160: 49-59.

Wang H and Woodson WR (1991) A flower senescence-related mRNA from carnation shares sequence similarity with fruit ripening-related mRNAs involved in ethylene biosynthesis. Plant Physiol., 96: 1000-1001.

Woltering EJ and Van Doorn W (1988) Role of ethylene in senescence of petals-morphological and taxonomical relationships. J. Exp. Bot., 39:1605-1616. 